\title{
Jihad in Classical and Modern Islam
}

Rudolph F. Peters. A Reader Markus Wiener Publishers, 1995. 214 pages.

Jihad in Classical and Modern Islam contains nine chapters, the first of which is a well constructed introduction that refers to various aspects and functions of jihad within the Islamic system of thought. This chapter introduces the reader to pertinent vocabulary of the jihad doctrine, setting the stage for the material throughout the book. Through the vocabulary, the author adroitly strings together a variety of texts in subsequent chapters which all utilize terms and concepts such as dar al-Islam, believers vs. unbelievers, takfir (declaring someone an unbeliever), expansionist jihad, defensive jihad, jihad as intemational law, greater and lesser jihad, and more. The chapters that follow the introduction present six Islamic texts translated from Arabic and Turkish, and the book concludes with two of the author's previously published articles on jihad. The aim of the book is to provide basic reading material on the doctrine and to highlight the various aspects of jihad and its development through the ages.

\section{Chapter 1: Jihad, An Introduction}

The author opens his case with a morphological and lexical analysis of the Arabic word jihad. In doing so, he successfully grounds the structure and contents of the entire book within the Arabo-Islamic conceptual framework. Such a grounding is crucial, as it helps debunk the unfortunate link between jihad and terrorism in the West - as well as in the East where abuse of the concept has lead to the obfuscation of pre-Islamic Arab ideas such as chivalry that in actuality "forbade worriers to kill non-combatants like children, women and old people." 


\section{Chapter 2: The Prophet's Lessons on Conduct in War}

In chapter two the reader is introduced to the first primary source, which consists of a number of hadiths, sayings and deeds of the Prophet, and in which are found prescriptions for proper conduct during warfare. Together with the Qur'an, hadiths form the raw material from which the body of Islamic law was elaborated, and the laws governing jihad are no exception. The hadiths chosen by the author are for the most part from the two most prestigious collections in Sunni Islam, the Sahih al-Bukhari and Muslim b. Hajjaj.

\section{Chapter 3: Exhortations to Jihad: Hadiths from Malik's al-Muwatta}

Chapter three deals with the second source, Malik ibn Anas's (d. 795) alMuwatta, which too is a collection of hadiths. The passages employed by Peters contain sayings of the Prophet and his Companions, exhorting the Muslims to participate in jihad and expounding the ultimate happiness of the martyrs slain in performing the duty of jihad. As a recognizable component of fundamentalist jihad, the element of martyrdom (or the relevance of the "martyr strategy") is surprisingly not elaborated by the author in later chapters within the context of the modern jihad doctrine.

\section{Chapter 4: The Legal Doctrine of Jihad: Ibn Rushd on Jihad}

In his choice of the third text, Peters proceeds from the eighth century to the twelfth with excerpts from Ibn Rushd's (d.1198) handbook on the legal doctrine of jihad and the arguments brought forward by theoreticians of the four Islamic legal schools (madhahab). Peters gives the reader an overview of the rules governing jihad, as interpreted by the various legal schools. The placement of this chapter following the chapters on hadiths enhances the structure of the book as it implies the way Islamic legal theory developed.

\section{Chapter 5: The Religious and Moral Doctrine of Jihad: Ibn Taymiyya on Jihad}

In the next chapter Peters moves to a later text, from the fourteenth century: Ibn Taymiyya's (d. 1328) Al-Siyasa al-Shar'iyya. The text, which contains a number of relevant Qur'anic verses and Prophetic hadiths demonstrates Ibn Taymiyya's concern with both internal struggles against fellow Muslims and external warfare against non-Muslims. The passages introduced by Peters thus appropriately deal with the definition of "enemy" 
within the context of the religious and moral aspects of the practice of jihad. The idea of defining the enemy within the context of appliance and purpose of jihad is picked up again later in Peters' articles on the practice of jihad in modern Islam and the relevance of the doctrine in certain political scenes.

\section{Chapter 6: Jihad and War Propaganda: the Ottoman Fatwa of 1914}

This text is a twentieth century fatwa (legal opinion), which, in conjunction with the declaration of war against the Allied Powers, was used by the Ottoman empire for war propaganda. Through the text of the fatwa. Peters illustrates how jihad may be used as a propaganda tool and is able to transfer smoothly the discussion of the doctrine of jihad to modern Islam and the twentieth century. The author returns to the idea of mass mobilization and jihad in chapter eight where modern and classical jihad literatures are compared with regard to this issue.

\section{Chapter 7: A Modernist Interpretation of Jihad: Mahmud Shaltut on Jihad}

This chapter presents the last of the translated texts. The brief text is a treatise on jihad in which the famous al-Azhar rector Shaykh Mahmud Shaltut (d. 1963) argues for a modernist and peaceful interpretation of jihad. With the inclusion of this treatise, Peters introduces jihad's peaceful facet in the context of modern Islamic thought. A more detailed treatment is offered in the author's article on the doctrine of jihad in modern history in chapter eight.

\section{Chapter 8: The Doctrine of Jihad in Modern Islam}

Chapter eight offers a follow-up analysis of the modernist interpretation of jihad that Peters by and large identifies with a moderate and peaceful interpretation, such as the one advocated by Shaykh Shaltut. The analysis, however, includes a discussion on the fundamentalist interpretation of the doctrine, thus giving the reading a somewhat confusing bifurcated picture: moderate modernist thought on the one hand vs. fundamentalist thought on the other. The fundamentalist interpretation is shown to adhere to strict application of certain elements in classical literature without necessarily taking into consideration contemporary social, economic and political developments.

The author compares and contrasts modern and classical jihad literature as to style and topics that are dealt with in both literatures. To this end, 
the author mentions types of struggles that are included in the definition of jihad, and compares the legal aims of jihad in modern and classical literatures, with emphasis on the differing political, economic and social conditions in the modern international arena. For instance, the author notes that in the classical literature, the legitimacy and propriety of initiating war against nations outside the boundaries of the abode of Islam is taken for granted and is hardly discussed. In modern writings, there is much discussion on the justification of the practice of jihad against non-Muslim nations. Though the author divided the discussion into three sections, the reader will find, as the author himself notes in the introduction to the chapter, that the sections on the definition of jihad, the legal aims of jihad, and the interpretation of the jihad doctrine as Islamic international law, all overlap in their scope.

\section{Chapter 9: The Relevance of the Jihad Doctrine in Sadat's Egypt}

The final chapter is a case study of the political role that the doctrine of jihad played in Anwar Sadat's Egypt in the 1970s. This context chosen by Peters underscores the fundamentalist interpretation in modern Islam. Particularly interesting is Peters' exposition of the role of jihad in national politics, where jihad constitutes an integral part of the ideology of the opposition Islamic movements. To these movements, jihad is identical with revolution, an instrumental or tactical concept, covering all kinds of activities conducive to the ultimate goal: the overthrow of the establishment and the restructuring of the political and social systems.

In summary, the author expounds the theme of jihad in wonderfully simple words and syntax, and the organization of the material as a whole allows readers with widely differing backgrounds to appreciate the integrity of the author's arguments. As the supporting material is not in English, the author's selection and translation of the original texts play a critical part in the material's accessibility to a broad audience without taking away from the quality of the analysis of the material. For the advanced student and scholar, perhaps, it is more interesting and useful to see the author's take on the applicability of the "classical" primary sources to modern Islam rather than the mere exposure to the Islamic sources, which the beginner will no doubt enjoy. Perhaps one of the most significant contributions of the book to the field of Middle Eastern Studies is the fact that it demonstrates quite poignantly the pertinence of "classical" material to our understanding of modern history and contemporary events. This conclusion becomes especially clear in the context of Peters' analysis of 
"fundamentalist thought" where the uncompromising application of jihad is often viewed as random violence. As Peters' analysis illustrates, the same "classical" material is the theoretical basis for a more peaceful, non-violent type of struggle.

Rebecca Molloy Independent Scholar 